\title{
LAWMAKING ISSUES IN THE REGULATION OF FINANCIAL RELATIONS
}

\author{
Nataliia Uvarova ${ }^{1}$, Oleg Mikhalskyi ${ }^{2}$, Igor Bohdaniuk ${ }^{3}$
}

\begin{abstract}
The aim of the article. The problematic issues of financial legislation are revealed, as well as the adoption of financial and legal provisions as one of the stages of financial legal regulation is considered. The subject of the study is lawmaking issues in the regulation of financial relations. Methodology. The study is based on an analysis of legal provisions regarding the legal regulation of financial relations in Ukraine. The comparative legal method enabled to study certain provisions of the legislation of Ukraine on financial relations, followed by the application of positive foreign experience in this sphere. The results of the study revealed the need for a detailed study of the problem. The most significant element for the existence and development of tax relations is considered. The author's approach to improving the tax legislation of Ukraine is exposed. Practical implications. Theoretical and legal foundations of financial relations in the economic and legal sphere are considered. A comparative legal study of legal provisions that affect the lawmaking issues in the regulation of financial relations and on this basis the definition of ways to improve the domestic legislation in this area. Relevance/originality. The analysis of financial relations raises the issue of codification and harmonization of tax legislation that mediate the development of the tax system since the efficiency of the tax system of Ukraine, the Russian Federation, and other countries depends on the uniformity of legal concepts used in the legal regulation of financial, banking, budgetary, tax activities.
\end{abstract}

Key words: law making, financial legislation, law enforcement, legal provisions, tax.

JEL Classification: K2, K3, K4

\section{The relevance of the topic}

The formation of Ukraine as a sovereign independent state requires the urgent solution of important social problems in a strict compliance with the provisions of modern national and international law. First, this concerns the improvement of social relations in public administration and implementation of state powers, search for ways to prevent social conflicts and their legal resolution. In the national legal framework, a large number of provisions establish a special procedure for the adoption of financial regulations that determine funds for the budget generation, sources of its revenue, targeted distribution and use. Therefore, the most important task is to define the forms and limits of the financial competence of state bodies, public and private entities authorized by the state to monitor compliance with tax legislation and bring to justice the subjects that violate this legislation.

\section{Literature review}

A significant contribution to the study of the place of the taxpayer in the legal mechanism of taxes was made by foreign and domestic scientists, such as

\footnotetext{
Corresponding author:

${ }^{1}$ Dnipropetrovsk State University of Internal Affairs, Ukraine.

${ }^{2}$ Kharkiv Research Institute of Forensic Examinations, Ukraine.

${ }^{3}$ Kharkiv Research Institute of Forensic Examinations, Ukraine.
}

S. S. Alekseev, I. V. Bilous, A. V. Demin, M. S. Kelman, D. A. Kerimov, A. P. Korenev, N. P. Kucheriavenko, O. H. Murashin, I. L. Nevzorov, V. S. Nersesiants, Ye. V. Pohorelov, T. N. Radko, O. Ya. Rohach, O. F. Skakun, A. I. Khudiakov. The aim of the article is to reveal the problematic issues of financial legislation, as well as to consider the adoption of financial and legal provisions as one of the stages of financial legal regulation.

\section{The main material}

The harmonization of existing legal provisions in the sphere of state power, such as the elimination of legal conflicts, compliance with international legal standards, coordination oflegal provisions to achieve consistency of legislation, is the key to the effective functioning of state bodies and local governments. While the application of the general provisions of law is investigated sufficiently fully in the general theory of law and occupies one of the central places of modern legal science, a special theoretical analysis of the application of the provisions of financial law is rare. In addition, scientific perspectives on the essence of the application of this type of legal provisions are fundamentally different. 
Unfortunately, in modern legal science, there is no unity in understanding the stages of applying the provisions of financial law, implementing regulations in this area. At the same time, the implementation of the provisions of financial law, specificity of legal nihilism in the financial sphere and others remain unattended Many controversial issues arise in the application of various financial and legal regulations. Therefore, the incorrect application of the provisions of tax legislation cannot give the state and society the necessary social effect.

According to S. S. Alekseev, the provisions of law should be studied from the perspective of the mechanism of legal regulation, that is, in the provisions of law, legal relations, a legal act, and other phenomena from the dogma of law and jurisprudence, the starting point and unifying source are theoretical provisions on legal regulation, especially its mechanism (Alekseev, 2009). Review of the legal regulation of social relations reveals the importance of the study of the provisions of law.

Therefore, according to A. P. Korenev, analysis of the issues of financial and legal regulation enables to conclude that financial and legal regulation, as well as administrative law, can be implemented in stages, in a certain sequence (Korenev, 1978). The authors of the article argue that financial and legal regulation consists of two stages, namely:

1) establishment of financial and legal provisions;

2) implementation of the provisions of financial law.

Therefore, the first stage is the establishment of the provisions of financial law. This activity consists of the adoption of financial and legal provisions, their improvement, change and cancellation, that is, the publication of legal regulations. It is well-known that lawmaking is a certain system of actions, such as the decision of the body on the need to develop draft legal regulations, the draft text preparation, its preliminary discussion by the relevant body, submission of the draft to the lawmaking body, adoption and approval of the draft, and publication of adopted legal regulations. It should be emphasized that in modern scientific legal literature, this term is understood rather differently. For example, according to A. F. Skakun, lawmaking is a legal form of state activity with the participation of civil society (in cases provided by law), associated with the establishment (authorization), change, cancellation of legal provisions (Skakun, 2001). According to M. S. Kelman, lawmaking is a form of power activity of authorized subjects (initially the state), aimed at creating legal regulations to introduce, change or cancel legal provisions (Kelman, Murashin, 2002). V. S. Nersesiants explains more extensively that lawmaking is a form of state activity aimed at creating legal provisions, as well as at their further improvement, modification, and abolition. This is the process of creating and developing existing law as a single and internally coordinated system of obligatory provisions that regulates social relations; this is a special activity for the establishment of legal regulation with a formal significance. The development and approval of new legal provisions are the main element in lawmaking (Nersesiants, 2006).

Traditionally, scientists consider that in its social essence, lawmaking is transforming state willpower into law, its formalization into various legal regulations, empowering rules of behaviour they contain, with a generally binding nature. Lawmaking is an important part of the whole process of law formation. According to T. M. Radko, lawmaking is the main way for the state to influence the life processes that require resolving. Lawmaking is an important indicator of state activity, its monopoly right (Radko, 2009).

Therefore, lawmaking is the formation of appropriate provisions by adopting appropriate laws and sub-statutory legal regulations (in state financial activities) by the competent authorities, and at the same time, one of the main links in legal regulation of relevant relations (financial and legal), which is a certain bridge in the implementation of financial and legal provisions. Some scholars emphasize that lawmaking generates legal regulation, and law enforcement concretizes it. However, enforcement of the provisions of law is not its development or refinement; it is the creation of a phenomenon of a different nature, on the "pattern" of abstract provisions. The law enforcement only regulates the specific situation in accordance with the will of the legislator.

That is why lawmaking is quite significant to implement financial and legal provisions. I. L. Nevzorov highlights, if laws contradict the needs of society and traditions of the people (the legislator fantasizes and "deceives"), law enforcement loses its essence since it becomes "bare lawlessness". At the same time, if laws meet the actual needs of society, the continuous development and improvement of legislation should take place (Nevzorov, 2002).

According to V. Nersesiants, lawmaking cannot stop at a certain stage but is always in a mobile state of development due to the dynamism of social ties, new needs of public life that require legal regulation (Nersesiants, 2006). Therefore, one of the permanent forms of development and rationalization of the existing legal system is the systematization of legislation. The term "systematization" (composed of parts, related to one another) is directly related to the category "system" and is derived from this word. A system is a set of interrelated elements that create an integrity and unity. Provisions, formulated in laws and other legal regulations, are put into practice, reality if they are implemented in deliberately volitional actions of citizens. In modern legal literature, systematization includes traditionally four independent forms of legal activity. As a rule, these include: (a) collection, elaboration, systematical arrangement, storage, etc. of existing legal regulations by state bodies, enterprises, and other institutions (accounting for regulations); (b) preparation and publication of various collections 
of regulations (incorporation of legislation); (c) preparation and adoption of consolidated acts based on joining regulations on individual issues (consolidation of legislation); (d) preparation and adoption of new regulations containing both provisions of the former justified regulations, as well as new regulatory prescriptions (codification of legislation). According to A. Rohach, the systematization of legislation is a generic concept that covers all activities aimed at streamlining legislation. Four independent forms of legislation systematization are codification, incorporation, consolidation, the current making of regulations (Rohach, 2003).

A. V. Demin argues that the higher the level of legislation systematization and orderliness, the fewer opportunities for its unreasonable interpretation, as well as for legal disputes and conflicts (Demin, 2008). According to E. V. Pohorelov, the systematization of legislation is the activity of rationalization and improvement of legislation, however, "rationalization of legislation" is not the aim of external systematization, and "improvement of legislation" is not the aim of internal systematization. Since the systematization of legislation is its improvement by rationalization of the content and form of legislation and consolidation of all existing legal regulations into a coherent, internally and externally agreed system (Pohorelov, 2000).

According to some scientists, the aim of systematization of tax legislation is manifested in the main areas, such as:

1) provision of stability and sustainability to legislation since stability is an integral feature of tax legislation, essential for a permanent system to regulate human relations;

2) increasing the role of tax laws by reducing substatutory, in particular, departmental legal regulations, since the priority of the tax law enables to achieve internal consistency and stability of tax regulation;

3) creation of technically flawless, perfect in the form, convenient for use tax legislation. In other words, availability, clarity, compactness of regulations, which are identical in structure, terminology, and writing style, enable to interpret and apply the provisions.

One of theimportant forms oflawmaking is codification, that is, a critical rethinking of existing legal provisions, elimination of contradictions and discrepancies between them. It is aimed at establishing new provisions that reflect the emerging needs of public life and fill the gaps in legal regulation to replace the obsolete legal regulations by new ones. D. A. Kerimov underlined the differences between codification and lawmaking activities because codification is the preparatory legislative activity of the relevant codification bodies. The scientist argues that such a formulation limits the entire lawmaking to the approval of legal regulations does not correspond to reality and contradicts the understanding of lawmaking. Codification work, as a rule, is not directly related to the current lawmaking activity and is carried out by special bodies, which, however, does not necessitate its separation from lawmaking in general. Even in the formation of legal acts from narrow separate current issues, the codification of relevant legislative material is often carried out by reproducing certain provisions of previously existing legal acts (Kerimov, 1955; Kerimov, 1962).

One of its types is a special codification, which includes regulations of a particular branch, institution, or a uniform complex of legislation. The result of codification is the adoption of codes, fundamentals of legislation, regulations, which always contain new provisions in a systematic way. To be precise, codification means restating regulations by eliminating contradictions, filling gaps, amendments. The common type of codified act is a code. Considering this, it is important to pay attention to the provisions of the domestic tax legislation on the example of the Tax Code of Ukraine.

It is well-known that at the present stage in Ukraine, tax reform is still ongoing. I. V. Belous argues that a clear understanding of rights and obligations by tax process participants, the absence of gaps and contradictions in the relevant legal framework are the basis of the effective functioning of the tax system (Bilous, 2011). Therefore, tax legislation, as well as sub-statutory regulations on taxation, is in a continuous development and improvement. At the same time, A. I. Khudiakov underlines that the legislator, encouraged by the practical needs, is improving existing legislation constantly. On the one hand, the gap between law and constantly changing public relations is reduced (that is, the legal superstructure complies with the economic basis), and on the other, a system of legislation is built enabling to study the system of public relations constantly (Khudiakov, 2010).

The tax legislation of Ukraine consists of the Constitution of Ukraine, the Tax Code, the Customs Code of Ukraine, and other customs laws on the regulation of legal relations arising from the taxation of duties on the movement of goods across the customs border of Ukraine; existing international agreements, agreed to be bound by the Verkhovna Rada of Ukraine, and which regulate the issues of taxation; legal regulations, adopted under and pursuant to the Tax Code of Ukraine and laws on customs matters; decisions of the Verkhovna Rada of the Autonomous Republic of Crimea, local authorities on local taxes and charges, adopted according to the rules established by the Tax Code (Podatkovyi kodeks Ukrainy).

The issue of codification and harmonization of tax legislation that mediate the development of the tax system since the efficiency of the tax system of Ukraine, the Russian Federation, and other countries depends on the uniformity of legal concepts used in the legal regulation of financial, banking, budgetary, tax activities. As noted, currently Ukraine is in need of the preparation of a permanent regulation providing for the 
basic principles of relationships arising in levying taxes and charges. The regulation, which to a greater extent should solve the tasks, is the Tax Code of Ukraine. It entered into force on January 1, 2011. Based on the general provisions of this legal regulation, some aspects should be considered.

This is not an exhaustive list of regulatory legal documents, but in future research, a more detailed analysis of this problem (Sevruk, 2017) on the regulation of financial relations should be made. Therefore, the implementation of foreign experience in national legislation will enable to create effective mechanisms (Pavlenko, 2017) of regulation of the tax legislation of Ukraine.

\section{Conclusion}

Therefore, the current Tax Code in its content and structure should consist of two classical parts: the General and the Special. The absence of such a distinction in the current edition introduces certain difficulties in the law enforcement of the provisions of the said codified regulation of the state. M. P. Kucheriavenko's perspective is extremely important when considering the concept of the Tax Code because he argues that the Tax Code should consist of four logical parts: General, Particular,
Special, and Tax Production (Kucheriavenko). This article advocates such an approach to the construction of the Tax Code and clarifies the architectonics of this codified regulation. Consequently, the Tax Code of Ukraine should include the General Part (combining a set of material and procedural provisions having a generalizing character and relevant to each section of the Particular Part) and the Special Part (consisting of narrower sets of material and procedural provisions regulating the collection of each individual tax or charge). In addition, forming the General Part of the Tax Code, it is advisable to divide the provisions, its components, into two sections: the first should cover mainly the material provisions regulating the execution of the tax obligation; the second should contain provisions regulating the process of administering taxes, charges (mandatory payments). At the same time, the section of the Tax Code that regulates the administration of taxes and charges (mandatory payments) has to differentiate provisions into several institutions: a) provisions that regulate the timely and full implementation of tax debt by payers; b) provisions that regulate the grounds and procedures for exercising tax control; c) provisions that regulate the administrative appeal; d) provisions that regulate tax violations and implementation of financial and legal sanctions for the violation of tax legislation.

\section{References:}

Alekseev, S. S. (2009). Obshchaia teoriia prava: uchebnik [The general theory of law: A teaching manual] (2nd ed.). M.: Prospectus, 576 p. (in Russian)

Korenev, A. P. (1978). Normy administrativnogo prava $i$ ikh primenenie [Norms of administrative law and their application]. M.: Juridical literature, 142 p. (in Russian)

Skakun, O. F. (2001). Teoriia derzhavy i prava: pidruchnyk [Theory of State and Law: A teaching manual]. Kh.: Konsum, 656 p. (in Ukrainian)

Kelman, M. S., Murashin, O. H. (2002). Zahalna teoriia prava (zi skhemamy, krosvordamy, testamy): pidruchnyk [General theory of law (with schemes, crossword puzzles, tests): A teaching manual]. K.: Condor, 583 p. (in Ukrainian) Nersesiants, V.S. (Ed.). (2006). Problemy obshchei teorii prava i gosudarstva: ucheb. dlia vuzov [Problems of the general theory of law and the state: A teaching manual]. M.: Norma, 832 p. (in Russian)

Radko, T. N. (2009). Teoriia gosudarstva i prava: ucheb. [Theory of State and Law: A teaching manual] (2nd ed.). M.: Prospekt, 752 p. (in Russian)

Nevzorov, I. L. (2002). Printsip zakonnosti v pravoprimenitelnoy deiatelnosti [The principle oflegality in law enforcement] (Dissertation of $\mathrm{PhD}$ in specialty 12.00.01). Kharkov, 196 p. (in Russian)

Rohach, O. Ya. (2003). Kodyfikatsiini akty v systemi zakonodavstva Ukrainy [Codification acts in the system oflegislation of Ukraine] (Dissertation of PhD in specialty 12.00.01). Uzhhorod, 209 p. (in Ukrainian)

Demin, A. V. (2008). Nalohovoe pravo Rossii: ucheb. posobie [Tax law of Russia: A teaching manual]. M.: RIOR, 380 p. (in Russian)

Pohorelov, Ye. V. (2000). Kodyfikatsiina diialnist v pravovii systemi Ukrainy [Codification activity in the legal system of Ukraine] (Dissertation of PhD in specialty 12.00.01). Kh., 166 p. (in Ukrainian)

Kerimov, D. A. (1955). Zakonodatelnaia deiatelnost Sovetskoho hosudarstva [Legislative activity of the Soviet state]. M.: Gosyurizdat, 134 p. (in Russian)

Kerimov, D. A. (1962). Kodifikatsiia i zakonodatelnaia tekhnika [Codification and legislative technique]. M.: Gosyurizdat, 104 p. (in Russian)

Bilous, I. V. (2011). Problemy zastosuvannia norm [Podatkovoho kodeksu Ukrainy Problems of application of the norms of the tax code of Ukraine] Proceedings from International Scientific and Practical Conference to the 10th anniversary of Scientific Institution on Financial Law in the XXI Century: Achievements and Prospects (October 4-7). K.: Alerta. (in Ukrainian)

Khudiakov, A. I. (2010). Izbrannye trudy po finansovomu pravu [Selected Works on Financial Law]. St.-P.: Judicial center - Press, 472 p. (in Russian) 
Podatkovyi kodeks Ukrainy [Tax code of Ukraine] (2011). Vidomosti Verkhovnoi Rady Ukrainy [Bulletin of the Verkhovna Rada of Ukraine], no. 13-14, no. 15-16, no. 17. Art. 3. (in Ukrainian)

Sevruk, V. H. (2017). Normatyvno-pravovi zasady protydii pravookhoronnymy orhanamy Ukrainy zlochynam, shcho vchyniayutsia orhanizovanymy hrupamy i zlochynnymy orhanizatsiiamy, yaki sformovani na etnichnii osnovi [Normative legal principles of counteraction of law enforcement bodies of Ukraine to crimes committed by organized groups and criminal organizations, which are formed on an ethnic basis]. Molodyi vchenyi, 4, 337-342. (in Ukrainian)

Pavlenko, S. O. (2017). Normatyvno-pravovi zasady protydii diialnosti destruktyvnykh relihiynykh orhanizatsii: vitchyzniani realii ta zarubizhnyi dosvid [Regulatory and legal principles of counteraction to the activities of destructive religious organizations: Domestic realities and foreign experience]. Pidpryiemnytstvo, hospodarstvo $i$ parvo [Entrepreneurship, Economy and Law], 2(252), 272-282. (in Ukrainian)

Kucheriavenko, N. P. Vvedenie $\mathrm{v}$ teoriiu nalohovogo prava [Introduction to the theory of tax law] (Vol. 2). Kurs nalohovogo prava [The course of tax law] (Vols. 1-6). Kharkov : Legas, 600 p. (in Russian) 